\title{
SOME ENGINEERING PROPERTIES OF COTTON SEEDS
}

\author{
M. M. Badr (1) and E. A. Darwish (2)
}

\begin{abstract}
To design equipment for application in plantation, harvesting, ginning, transportation, storage, oil extraction and processing operations of cotton seeds, the knowledge of various engineering properties for cotton seeds. The study of experiments conducted on cotton seeds at $9.16 \%$ moisture content on dry basis. The results showed that the average value of length, width, thickness, geometrical and arithmetic mean diameters, volume, sphericity, coefficient of contact surface and surface area of cotton seeds were 9.47, 5.57, 4.68, 6.27, $6.58 \mathrm{~mm}, 129.55 \mathrm{~mm}^{3}, 66.37 \%$, $50.32 \%$ and $123.63 \mathrm{~mm}^{2}$, respectively. While; the mean value of bulk and true densities, individual seed mass, one thousand seed, porosity and projected area were 0.457 and $1.051 \mathrm{~g} / \mathrm{cm}^{3}, 0.115 \mathrm{~g}, 112.22 \mathrm{~g}, 56.39 \%$ and $39.91 \mathrm{~mm}^{2}$, respectively. The study also revealed that the average value of repose angle was $36.22^{\circ}$. While; the lowest value of static friction coefficient for cotton seeds were on stainless steel sheet followed by galvanized iron, plywood and the highest on rubber were 0.320, 0.408, 0.482 and 0.583 , respectively. The study also concluded that the mean value of rupture force and deformation ratio of cotton seeds were $76.88 \mathrm{~N}$ and $6.11 \%$. The mean values of terminal velocity and coefficient of drag were $9.34 \mathrm{~m} / \mathrm{s}$ and 0.55 , respectively. Also; the mean value of Reynolds number was 3536 so; the pattern of air flow is in the range of transitional flow.
\end{abstract}

\section{INTRODUCTION}

otton is cultivated in many parts of the world as a source of food
(edible vegetable oil), fiber and feed (oil cake). Cotton seeds
contains about $17-24 \%$ oil and $40-43 \%$ protein (Ozarslan, 2002).

Zewdu and Solomon (2008) told that the bulk density and porosity are crucial properties in the development of the aeration and drying systems as these properties affect the resistance to airflow of stored mass.

(1) Assoc. Prof. and (2) Lecturer, Agric. Products Processing Eng. Dept.; Fac. of Agric. Eng.; Al-Azhar Univ.; Cairo; Egypt. 
Mohsenin (1986) mentioned that the physical properties of agricultural material such as; shape and size, volume, density, porosity and surface area are important and essential engineering data in many problems associated with design of machines or analysis of the behavior of the agricultural products in different processes.

Ozarslan (2002) measured physical properties of cotton seeds. The average length, width and thickness of cotton seeds ranged from 9.02 to $9.19,4.70$ to 4.86 and 4.25 to $4.45 \mathrm{~mm}$, as the moisture content increased from 8.33 to $13.78 \%$ (d.b.) respectively. In the same moisture range, studies on rewetted cotton seeds showed that the sphericity increased from 0.626 to 0.635 , seed volume from 95.4 to $109.6 \mathrm{~mm}^{3}$, thousand seed mass from 104.06 to $109.64 \mathrm{~g}$ and projected area from 35.89 to 40.14 $\mathrm{mm}^{2}$. While; the bulk and true densities decreased from 642 to 610 and 1091 to $1000 \mathrm{~kg} / \mathrm{m}^{3}$ respectively.

Asadzadeh (2014) reported that the physical properties of cotton seeds were evaluated as a function of moisture content. The results showed that the average value of length, width, thickness, projected area, sphericity and thousand seed mass of seed ranged from 9.07 to $9.28,4.87$ to 5.5.02, 4.57 to $4.70 \mathrm{~mm}, 49.85$ to $52.25 \mathrm{~mm}^{2}, 64.67$ to $65.02 \%$ and 99.09 to $107.52 \mathrm{~g}$, as the moisture content increased from 7.17 to $13 \%$ d.b., respectively. While; the mean value of true density and porosity decreased from 1048.5 to $983.3 \mathrm{~kg} / \mathrm{m} 3$ and 44.04 to $42.26 \%$, respectively.

Vasuki and Tajuddin (2015) examined some physical properties of cotton seeds. They found that the sphericity of seeds ranged from 0.636 to 0.687, thousand seed mass from 61.60 to $93.6 \mathrm{~g}$, bulk density varied from 613 to $648 \mathrm{~kg} / \mathrm{m}^{3}$, the angle of repose varied from 19.2 to $26.3^{\circ}$ and true density varied from 989 to $1000 \mathrm{~kg} / \mathrm{m}^{3}$.

The aim of this study was to investigate some engineering characteristics of the cotton seeds which affect designing and developing of precision planting, handling system, storage, ginning and separation machines. 


\section{MATERIALS AND METHODS}

\subsection{Materials}

The experimental part of the present study was carried out in the Agricultural Products Process Engineering Laboratory at the Faculty of Agricultural Engineering Al-Azhar University, Egypt. The used cotton seeds (Giza 94) were provided by agricultural research center. The seeds were cleaned manually to remove all foreign matter such as dust, dirt, stones and fiber as well as immature, broken, and fuzzy seeds.

\subsection{Physical properties of cotton seeds}

Physical properties of cotton seeds were measured. The measured properties included moisture content, seed dimensions and related characteristics, individual seed mass, one thousand seed, bulk and true densities, porosity and projected area.

\subsubsection{Moisture content}

The moisture content of cotton seeds can be determined by drying to constant weight in an oven at $105 \pm 1^{\circ} \mathrm{C}$ according to (AOAC, 2005), moisture content can be calculated on dry basis as follows:

$$
\text { M. } C=\frac{M_{m}}{M_{d}} \times 100
$$

Where: $M_{m}$ : Mass of moisture in sample, $(\mathrm{g})$; and $\mathrm{M}_{\mathrm{d}}$ : Mass of bone-dry sample, $(\mathrm{g})$.

\subsubsection{Principal dimensions of cotton seeds}

A digital caliper with accuracy of $0.01 \mathrm{~mm}$ was used to measure the length (L), width (W) and thickness (T) for cotton seeds. The average length, width and thickness of one hundred seed were calculated.

\subsubsection{Related characteristics of seeds principal dimensions:}

\section{a) Average diameters and volume}

Geometric mean diameter $\left(D_{g}\right)$, arithmetic mean diameter $\left(D_{a}\right)$ and the calculated volume $\left(\mathrm{V}_{\text {cal. }}\right)$ of cotton seeds calculated using the following equations, according to (Ghanem et al. 2017):

$$
\mathrm{D}_{\mathrm{g}}=(\mathrm{LWT})^{1 / 3} \ldots \ldots \ldots(2) \quad \mathrm{D}_{\mathrm{a}}=(\mathrm{L}+\mathrm{W}+\mathrm{T}) / 3
$$




$$
\mathrm{V}_{\text {cal. }}=\frac{\pi}{6}[\mathrm{LWT}] \ldots \ldots
$$

\section{b) Sphericity}

Movement of spherical seed is usually higher under gravity than nonspherical seeds. The sphericity of seeds $(\varnothing)$ was calculated by using the following relationship (Mohsenin, 1986):

$$
\varnothing=\frac{(\mathrm{LWT})^{1 / 3}}{\mathrm{~L}} \times 100
$$

\section{c) Coefficient of contact surface}

Coefficient of contact surface (C.C) was calculated for seeds according to (Abd Alla, 1995):

$$
\text { C. } C=\frac{A_{f}-A_{t}}{A_{f}} \times 100
$$

Where: $A_{f}:$ Area of flat surface $=\frac{\pi}{4}(\mathrm{LW}), \mathrm{mm}^{2}$; and

$A_{t}:$ Area of transverse surface $=\frac{\pi}{4}(\mathrm{WT}), \mathrm{mm}^{2}$.

\section{d) Surface area}

The surface area of seeds $\left(A_{s}\right)$ depends on values of geometric mean diameter as in the following formula, according to (Adejumo et al. 2015).

$$
\mathrm{A}_{\mathrm{s}}=\pi \mathrm{D}_{\mathrm{g}}^{2}
$$

\subsubsection{Bulk and true densities of seeds:}

Bulk density of the seeds is used for seed storage structures designs. It was measured using a graduated flask having a volume of $25 \mathrm{~cm}^{3}$. The graduated flask was filled with cotton seeds without compaction and then its weight was measured. The bulk density " $\rho_{\mathrm{b}} "\left(\mathrm{~g} / \mathrm{cm}^{3}\right)$ was calculated as the following equation (8). The true density " $\rho_{\mathrm{t}}$ " $\left(\mathrm{g} / \mathrm{cm}^{3}\right)$ was determined using a toluene $\left(\mathrm{C}_{7} \mathrm{H}_{8}\right)$ displacement method with a known mass of seeds. It was calculated using the following equation (Mohsenin, 1986).

$$
\rho_{\mathrm{b}}=\frac{\mathrm{M}}{\mathrm{V}_{\mathrm{s}}} \ldots \ldots \ldots \ldots \ldots \ldots \text { (8) } \quad \rho_{\mathrm{t}}=\frac{\mathrm{M}}{\mathrm{V}_{\mathrm{t}}}
$$


Where: $\mathrm{M}_{\mathrm{s}}$ : Mass sample, $(\mathrm{g}) ; \mathrm{V}_{\mathrm{s}}$ : Volume of bulk sample, $\left(\mathrm{cm}^{3}\right)$; and $\mathrm{V}_{\mathrm{t}}$ : Displaced volume of toluene, $\left(\mathrm{cm}^{3}\right)$.

The procedure was repeated ten times and the average bulk and true densities of the cotton seeds were reported.

\subsubsection{Mass of seeds}

The mass of single seed $\left(\mathrm{M}_{\mathrm{i}}\right)$ was determined by randomly selecting one hundred seed of cotton and then weighing them one by one. A precision weighing balance having least count of $0.01 \mathrm{~g}$ was used. To determine the one thousand seed mass, three hundred seeds were selected and weighed, then divided to three groups, each group contains one hundred seed. The mass of thousand seed $\left(\mathrm{M}_{\mathrm{t}}\right)$ was determined by multiplying the average mass of one hundred seeds by ten.

\subsubsection{Porosity}

Porosity affects the resistance to airflow through the bulk material bed and data on them are necessary in designing the drying process. The porosity of cotton seeds $(\varepsilon)$ depends on values of bulk and true densities using the following equation according to, (Mohsenin, 1986).

$$
\varepsilon=\left(1-\frac{\rho_{\mathrm{b}}}{\rho_{\mathrm{t}}}\right) \times 100
$$

Bulk density and true densities values obtained from previous experiments were used to calculate the porosity of the cotton seeds.

\subsubsection{Projected area of cotton seed}

To determine the projected area of cotton seeds $\left(A_{p}\right)$, fifty seeds were randomly selected from cotton seeds and then scanned using a scanner to capture the image of seeds at natural flat position, then; the pictures of seeds were exported to SolidWorks, program to calculate the projected area of cotton seeds.

\subsection{Mechanical properties of cotton seed:}

\subsubsection{Repose angle}

The repose angle is the angle between the base and the slope of cone formed on a free vertical fall of the seeds mass to a horizontal plane. The slope of base of the seed flow structures is based on the average angle of 
repose of seeds to ensure free flow of seeds. The dynamic angle of repose of seeds was measured by a hollow cylinder $(80 \mathrm{~mm}$ diameter and 200 $\mathrm{mm}$ height) and a wooden table. The cylinder was placed on the wooden table. Then; it was filled with cotton seeds. The cylinder was raised slowly allowing the seeds to flow down to form a cone of seeds and then diameter and height of the seeds cone were measured and recorded. The repose angle was calculated as the following equation (11).

\subsubsection{Static friction coefficient}

The coefficient of friction between seed and wall is an important parameter in the prediction of seed pressure on walls. Static friction coefficient of seeds was determined on four different materials namely; plywood $\left(\mathrm{P}_{\mathrm{w}}\right)$, galvanized iron $\left(\mathrm{G}_{\mathrm{i}}\right)$, rubber $\left(\mathrm{R}_{\mathrm{b}}\right)$ and stainless steel $(\mathrm{Ss})$. In order to determine coefficient of friction a sample was put on the surface with adjustable slope. When a sample started to move, the tangent of the slope angle calculate. The procedure was repeated ten times and the static friction coefficient for each replicate was calculated using the following equation:

$$
\alpha=\tan ^{-1}\left[\frac{2 \mathrm{H}}{\mathrm{D}}\right] \ldots \ldots \ldots \ldots(11) \quad \mu \ldots \tan \beta
$$

Where: $\alpha$ : Repose angle, (degree); $\mathrm{H}$ : Height of the cone, (cm); D: Diameter of the cone, $(\mathrm{cm}) . \mu$ : Static friction coefficient; and $\beta$ : Angle of friction, (degree).

\subsubsection{Rupture force and deformation ratio}

Rupture force $\left(R_{f}\right)$ is implies the partial or complete destruction of seed. The rupture force and deformation ratio of seeds were measured by using a digital Universal Material Tester. The specifications of device were as follows: Model No: MT 2021, range of the measurement is 0 to $20 \mathrm{kN}$ and its accuracy is $0.1 \mathrm{~N}$. The used sample for measure the rupture force was 25 seed. Seed is set upon a flat plate until the crosshead of apparatus was brought in contact with the seed and a compression force was applied until permanent (destruction) was caused. The readings are recorded over a digital screen. The deformation ratio at rapture point $\left(D_{r}\right)$ is the 
longitudinal strain at rupture point and it was calculated by the following equation, according to (Mousa et. al., 2016):

$$
\mathrm{D}_{\mathrm{r}}=\frac{\mathrm{y}}{\mathrm{d}} \times 100
$$

Where: y: Deformation at rapture point "change in dimension", (mm); and d: Original dimension of seed, (mm).

\subsection{Aerodynamic properties of cotton seed:}

\subsubsection{Terminal velocity and drag coefficient}

The terminal velocities of cotton seeds were measured using the terminal velocity apparatus Fig.1 according to (Awady and El-Sayed, 1994). The apparatus consists of a rectangular tube constructed from transparent (plexi-glass) and connected with the outlet of the electric blower, two wire screens were fitted at the bottom and top of the transparent tube, an air-flow straightener was attached with the lower screen to improve flow uniformity throw the rectangular tube, a choke valve is built as the inlet of

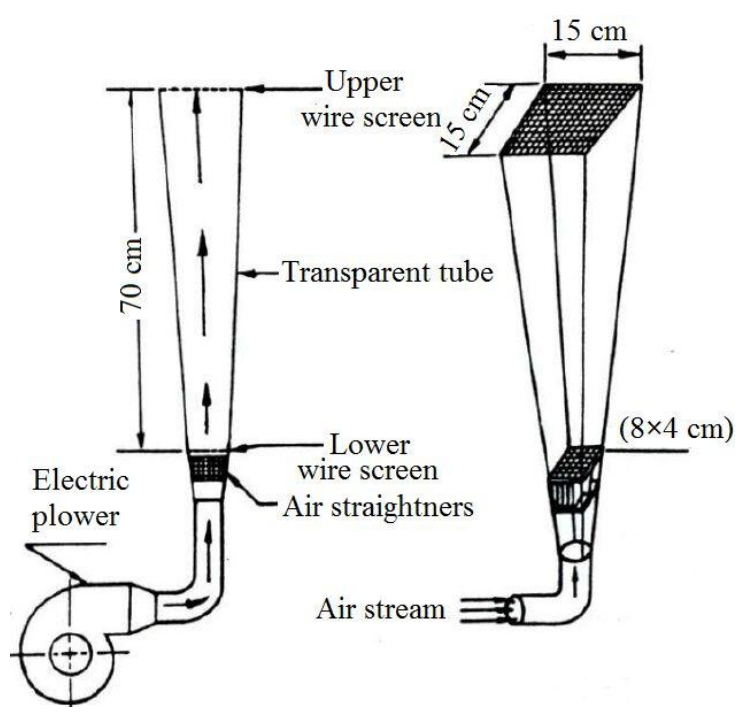
Fig. 1: Terminal air velocity setup (Awady and El-sayed, 1994). blower to control the air flow rate manually.

The sample was placed on the lower screen. Terminal velocity can be obtained by measuring the air velocity required to suspend the particles in the vertical air stream. Air velocity was measured at the bottom of the tube by an anemometer. The air velocity changes according to changes in the cross-section of the tube. The value of the terminal velocity $\left(\mathrm{V}_{\mathrm{t}}\right)$ " $\mathrm{m} / \mathrm{s} "$ was calculated using the following equation: 


$$
\mathrm{V}_{\mathrm{t}}=\frac{\mathrm{Q}}{\mathrm{A}}
$$

Where: Q: Air flow rate, $\left(\mathrm{m}^{3} / \mathrm{s}\right)$; and A: Cross-section area of the tube, $\left(\mathrm{m}^{2}\right)$.

When a particle is suspended into a turbulent stream of air, equilibrium is achieved between its weight and the drag force, the drag coefficient $\left(C_{d}\right)$ of seed was calculated by the following equation according to (Awady and El- sayed, 1994):

$$
C_{d}=\frac{2 M \cdot g}{V_{t}^{2} \cdot \rho_{a} \cdot A_{p}} \ldots \ldots \ldots \ldots \ldots \cdots \cdots \cdots \cdots
$$

Where: M: Mass of seed, $(\mathrm{kg})$; g: Acceleration of gravity, $\left(9.81 \mathrm{~m} / \mathrm{s}^{2}\right) ; \mathrm{V}_{\mathrm{t}}$ : Air terminal velocity, $(\mathrm{m} / \mathrm{s}) ; \rho_{a}$ : Air density $\left(1.2 \mathrm{~kg} / \mathrm{m}^{3}\right)$; and $\mathrm{A}_{\mathrm{p}}$ : Projected area of seed, $\left(\mathrm{m}^{2}\right)$.

\subsubsection{Reynolds number}

Reynolds number $\left(\mathrm{R}_{\mathrm{n}}\right)$ "dimensionless" was calculated by the following equation (Mohsenin, 1986).

$$
\mathrm{R}_{\mathrm{n}}=\frac{\rho_{\mathrm{a}} \cdot \mathrm{V}_{\mathrm{t}} \cdot \mathrm{D}_{\mathrm{g}}}{\mu}
$$

Where: $D_{g}$ : Geometric mean diameter, $(\mathrm{m})$; and $\mu$ : Dynamic viscosity of air, $\left(18 \times 10^{-6} \mathrm{~kg} / \mathrm{m} . \mathrm{s}\right)$.

The laminar flow is at $R_{n} \leq 2100$, transitional flow at $2100<R_{n}<4000$ and turbulent flow is at $R_{n} \geq 4000$.

\section{RESULTS AND DISCUSSIONS}

All experiments of physical, mechanical and aerodynamic properties were carried out under the average moisture content of $9.16 \pm 0.57 \%$ d.b.

\subsection{Physical properties}

Based on the experiments conducted in the laboratory for each mentioned property of cotton seeds, the results are as follows:

\subsubsection{Seeds principal dimensions}

The principal dimensions of cotton seeds were taken with the help of a digital caliper. The average value of length was $9.47 \pm 0.65 \mathrm{~mm}$, varying in range from 8.12 to $10.48 \mathrm{~mm}$, whilst; the mean values of width and 
thickness were $5.57 \pm 0.33$ and $4.68 \pm 0.31 \mathrm{~mm}$ which ranged from 4.92 to 6.45 and 4.02 to $5.19 \mathrm{~mm}$, respectively, as shown in Table 1 .

Table 1: Physical properties (seeds principal dimensions and related characteristics of principal dimensions) of cotton seeds

\begin{tabular}{|c|c|c|c|c|c|}
\hline \multirow{2}{*}{ Parameter } & \multirow{2}{*}{ Symb. } & \multicolumn{2}{|c|}{ Range } & \multirow{2}{*}{ Mean \pm SD } & \multirow{2}{*}{$\begin{array}{l}\mathrm{CV}, \\
(\%)\end{array}$} \\
\hline & & Min. & Max. & & \\
\hline Moisture content, (d.b) & M.C & 8.19 & 9.78 & $9.16 \pm 0.57$ & 6.27 \\
\hline \multirow{3}{*}{ Principal dimensions, $(\mathrm{mm})$} & $\mathrm{L}$ & 8.12 & 10.48 & $9.47 \pm 0.65$ & 6.85 \\
\hline & $\mathrm{W}$ & 4.92 & 6.45 & $5.57 \pm 0.33$ & 5.52 \\
\hline & $\mathrm{T}$ & 4.02 & 5.19 & $4.68 \pm 0.31$ & 6.56 \\
\hline \multirow{2}{*}{ Average diameter, $(\mathrm{mm})$} & $D_{g}$ & 5.66 & 6.86 & $6.27 \pm 0.25$ & 3.93 \\
\hline & $\mathrm{D}_{\mathrm{a}}$ & 5.98 & 7.20 & $6.58 \pm 0.27$ & 4.16 \\
\hline Calculated volume, $\left(\mathrm{mm}^{3}\right)$ & $\mathrm{V}_{\text {cal. }}$ & 94.81 & 169.08 & $129.55 \pm 15.29$ & 11.80 \\
\hline Sphericity, (\%) & $\varnothing$ & 58.80 & 75.77 & $66.37 \pm 3.55$ & 5.35 \\
\hline $\begin{array}{l}\text { Coefficient of contact } \\
\text { surface, }(\%)\end{array}$ & C.C & 40.02 & 60.94 & $50.32 \pm 4.72$ & 9.38 \\
\hline Surface area, $\left(\mathrm{mm}^{2}\right)$ & $A_{s}$ & 100.55 & 147.87 & $123.63 \pm 9.71$ & 7.86 \\
\hline
\end{tabular}

\subsubsection{Related characteristics of principal dimensions of cotton seeds}

\section{1) Average diameters and volume}

From Table 1 the mean value of geometric mean diameter was $6.27 \pm$ $0.25 \mathrm{~mm}$ and it varied in range from 5.66 to $6.86 \mathrm{~mm}$. While; the mean value of arithmetic mean diameter was $6.58 \pm 0.27 \mathrm{~mm}$ which ranged between 5.98 to $7.20 \mathrm{~mm}$. Also; the mean value of calculated volume was $129 \pm 15.29 \mathrm{~mm}^{3}$ and it varied in range from 94.81 to $169.08 \mathrm{~mm}^{3}$.

\section{2) Sphericity}

As shown in Table 1 the mean sphericity of the seeds was recorded as $66.37 \pm 3.55 \%$, which ranged between $58.80 \%$ and $75.77 \%$. This characteristic is considered to be helpful for separation and grading machines.

\section{3) Coefficient of contact surface and surface area}

According Table 1 the value of coefficient of contact surface ranged from 40.02 to $60.94 \%$ with an average value of $50.32 \pm 4.72 \%$. Meanwhile; the 
average value of surface area was found to be $123.63 \pm 9.71 \mathrm{~mm}^{2}$, which ranged from 100.55 to $147.87 \mathrm{~mm}^{2}$.

\subsubsection{Bulk and true densities}

The average value of bulk density of the seeds was $0.457 \pm 0.02 \mathrm{~g} / \mathrm{cm}^{3}$, ranging from 0.435 to $0.491 \mathrm{~g} / \mathrm{cm}^{3}$. While; the mean true density of the seeds was recorded as $1.051 \pm 0.06 \mathrm{~g} / \mathrm{cm}^{3}$, which ranged between 0.990 and $1.148 \mathrm{~g} / \mathrm{cm}^{3}$, according Table 2 .

Table 2:Physical properties (density, mass, porosity and projected area)

\begin{tabular}{|lc|c|c|c|c|}
\hline \multirow{2}{*}{ Parameter } & \multirow{2}{*}{ Symb. } & \multicolumn{2}{|c|}{ Range } & \multirow{2}{*}{ Mean \pm SD } & $\begin{array}{c}\text { CV, } \\
(\%)\end{array}$ \\
\cline { 3 - 6 } & Min. & Max. & & 4.27 \\
\hline \hline \multirow{2}{*}{ Density, $\left(\mathrm{g} / \mathrm{cm}^{3}\right)$} & $\rho_{\mathrm{b}}$ & 0.435 & 0.491 & $0.457 \pm 0.02$ & 4.62 \\
\cline { 2 - 5 } & $\rho_{\mathrm{t}}$ & 0.990 & 1.148 & $1.051 \pm 0.06$ & 5.62 \\
\hline \multirow{2}{*}{ Mass, $(\mathrm{g})$} & $\mathrm{M}_{\mathrm{i}}$ & 0.071 & 0.153 & $0.115 \pm 0.02$ & 16.00 \\
\hline \hline Porosity, (\%) & $\mathrm{M}_{\mathrm{t}}$ & 109.60 & 115.40 & $112.22 \pm 2.44$ & 2.18 \\
\hline Projected area, $\left(\mathrm{mm}^{2}\right)$ & $\varepsilon$ & 53.85 & 60.18 & $56.39 \pm 2.38$ & 4.23 \\
\hline \hline
\end{tabular}

\subsubsection{Mass of cotton seeds}

Table 2 showed that the values of individual seeds masses varied from 0.071 to $0.153 \mathrm{~g}$ with an average value of $0.115 \pm 0.02 \mathrm{~g}$. Whereas; the average mass of one thousand seeds varied from 109.60 to $115.40 \mathrm{~g}$ with an average value of $112.22 \pm 2.44 \mathrm{~g}$.

\subsubsection{Porosity and projected area}

From Table 2 the mean values of porosity and projected area were 56.39 $\pm 2.38 \%$ and $39.91 \pm 1.93 \mathrm{~mm}^{2}$, these values ranged from 53.85 to $60.18 \%$ and 38.12 to $43.88 \mathrm{~mm}^{2}$, respectively. These characteristics are also beneficial for separation and grading machines.

\subsection{Mechanical properties}

\subsubsection{Repose angle}

The average value of repose angle was found to be $36.22 \pm 2.39^{\circ}$ which ranged from $32.21^{\circ}$ to $38.31^{\circ}$, as shown in Table 3. This characteristic can 
be utilized to assess the optimum side's inclination of seed hopper in ginning machines, silos and storage containers to allow an easily sliding.

Table 3: Mechanical properties of cotton seeds.

\begin{tabular}{|c|c|c|c|c|c|}
\hline \multirow{2}{*}{ Parameter } & \multirow{2}{*}{ Symb. } & \multicolumn{2}{|c|}{ Range } & \multirow{2}{*}{ Mean \pm SD } & \multirow{2}{*}{$\begin{array}{l}\mathrm{CV}, \\
(\%) \\
\end{array}$} \\
\hline & & Min. & Max. & & \\
\hline Repose angle, (degree) & $\alpha$ & 32.21 & 38.31 & $36.22 \pm 2.39$ & 6.59 \\
\hline \multirow{4}{*}{ Static friction coefficient } & $\mathrm{P}_{\mathrm{w}}$ & 0.410 & 0.560 & $0.482 \pm 0.05$ & 11.00 \\
\hline & $\mathrm{G}_{\mathrm{i}}$ & 0.360 & 0.455 & $0.408 \pm 0.03$ & 8.38 \\
\hline & $\mathrm{R}_{\mathrm{b}}$ & 0.525 & 0.671 & $0.583 \pm 0.04$ & 7.63 \\
\hline & Ss & 0.240 & 0.375 & $0.320 \pm 0.04$ & 13.99 \\
\hline Rupture force, $(\mathrm{N})$ & $\mathrm{R}_{\mathrm{f}}$ & 60.80 & 91.40 & $76.88 \pm 10.32$ & 13.43 \\
\hline Deformation ratio, $(\%)$ & $D_{r}$ & 4.10 & 7.73 & $6.11 \pm 1.15$ & 18.77 \\
\hline
\end{tabular}

\subsubsection{Static friction coefficient}

According to Table 3 the lowest values of static friction coefficient were on stainless steel sheet followed by galvanized iron, plywood and the highest on rubber $(0.320$, $0.408,0.482$ and 0.583 ), respectively. This is due to the smoother and more polished surface of stainless steel sheet and galvanized iron than the other tested surfaces. As shown in Fig. 1.

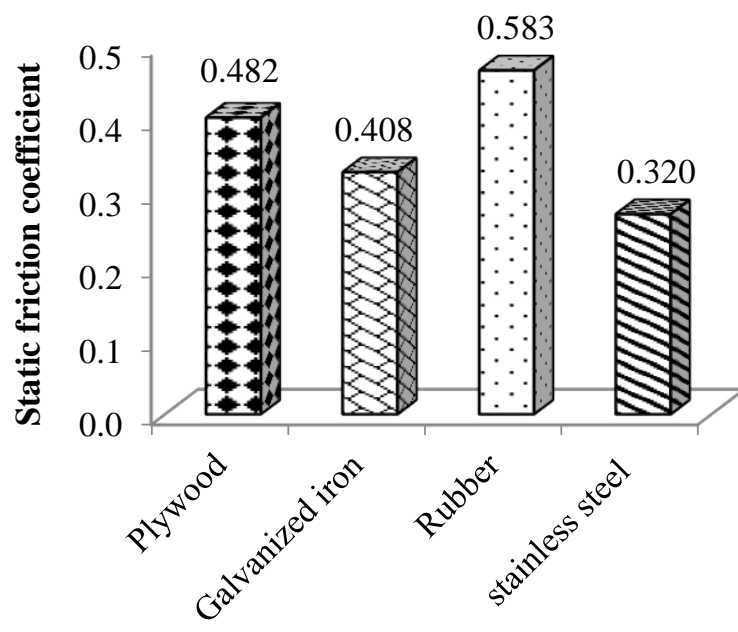

Type of surface

Fig. 1: Static friction coefficient for cotton seeds on different material surfaces

\subsubsection{Rupture force and deformation ratio}

The results showed that the mean values of rupture force and deformation ratio of cotton seeds were found to be $76.88 \pm 10.32$ and $6.11 \pm 1.15 \%$ which 
ranged from 60.80 to $91.40 \mathrm{~N}$ and 4.10 to $7.73 \%$, as shown in Table 3 .This characteristic is beneficial for extract oil from cotton seeds.

\subsection{Aerodynamic properties}

\subsubsection{Terminal velocity and drag coefficient}

The results showed that the values of terminal velocity and coefficient of drag for seeds varied from 8.28 to $10.54 \mathrm{~m} / \mathrm{s}$ and 0.42 to 0.69 with average values of $9.34 \pm 0.58 \mathrm{~m} / \mathrm{s}$ and $0.55 \pm 0.07$, with coefficient of variation as $6.26 \%$ and $12.49 \%$ respectively, These characteristics can be utilized in designing air screen, cleaning and grading equipment.

\subsubsection{Reynolds number}

The mean value of Reynolds number was $3536 \pm 221$ ranging from 3135 to 3991 with coefficient of variation as $6.26 \%$. The results showed that the pattern of air flow is in the range of transitional flow.

\section{CONCLUSIONS}

The study of experiments conducted on cotton seeds at $9.16 \%$ moisture content on dry basis revealed the following conclusions:

- The mean values of length, width, thickness, geometrical and arithmetic mean diameter were 9.47, 5.57, 4.68, 6.27 and $6.58 \mathrm{~mm}$, respectively. Also; the average values of volume, sphericity, coefficient of contact surface and surface area were $129.55 \mathrm{~mm}^{3}$, $66.37 \%, 50.32 \%$ and $123.63 \mathrm{~mm}^{2}$, respectively.

- The study also concluded that the mean values of bulk and true densities of cotton seeds were 0.457 and $1.051 \mathrm{~g} / \mathrm{cm}^{3}$, respectively. In addition to that the average values of individual seed mass and one thousand seed were 0.115 and $112.22 \mathrm{~g}$, respectively. Also; the mean values of porosity and projected area were $56.39 \%$ and $39.91 \mathrm{~mm}^{2}$, respectively.

- The average value of repose angle was $36.22^{\circ}$. While; the lowest values of static friction coefficient for cotton seeds were on stainless steel followed by galvanized iron, plywood and the highest on rubber were $0.320,0.408,0.482$ and 0.583 respectively. The study also concluded that the mean values of rupture force and deformation ratio of seeds was $76.88 \mathrm{~N}$ and $6.11 \%$ respectively. 
- The mean values of terminal velocity and coefficient of drag were 9.34 $\mathrm{m} / \mathrm{s}$ and 0.55 respectively. While; the mean value of Reynolds number was 3536 so; the pattern of air flow is in the range of transitional flow.

\section{REFERENCES}

Abd Alla, H. E.; S. M. Radwan and E. H. El Hanafy (1995). Effect of some physical properties of rice grains on milling quality. Misr J. Ag. Eng. 12 (1): 143-155.

Adejumo, A.O.; E. A. Ajav and J.C. Igbeka (2015). Effects of variety and moisture content on some physical properties of cotton pod. J. AJER. 4 (4): 27-33.

AOAC (2005). Official methods of analysis. Association of official analytical Chemists. Published by the AOAC. Int. 18th ed. Washington, D.C.

Asadzadeh, A. H. (2014). Some physical properties of cotton seed at different moisture contents. J. ICAE.15 (2): 205-214.

Awady M. N. and A. S. El-Sayed (1994). Separation of peanut seeds by air stream. Misr J. Ag. Eng., 11(1): 137-147.

Ghanem, T. H.; K. S. Nagy.; M. M. Badr and E. A. Darwish (2017). Some physical and mechanical properties of Sodom apple (Calotropis Procera). Misr J. Ag. Eng., 34(2): 1009 - 1022.

Mohsenin N. N. (1986). Physical properties of plant and animal materials. Gordon and Breach Sc. Publ., N.Y.

Mousa, A. M.; N. S. Elkaoud and S. H. Dosoky (2016). Physical, mechanical and aerodynamic properties of Jatropha seeds. Misr J. Ag. Eng., 33(4): 1477 - 1496.

Ozarslan, C. (2002). Physical properties of cotton seed. J. Biosystems Eng. 83(2): 169-174

Vasuki. G and A. Tajuddin (2015). A study on physical properties of cotton seeds for developing a high density cotton planter. J. IJASR. 5 (4): 49-52.

Zewdu A. D. and W. K. Solomon (2006). Moisture dependent physical properties of grass pea seeds. J. Ag. Eng. Int. 96 (1): 57- 63. 


\section{الملخص العربى \\ بعض الخصائص الهندسية لبذور القطن

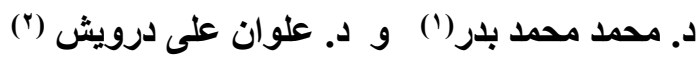

يعد القطن ملك محاصيل الألياف ومن أهم المحاصيل التجارية التي تزرع في بلدان كثيرة من

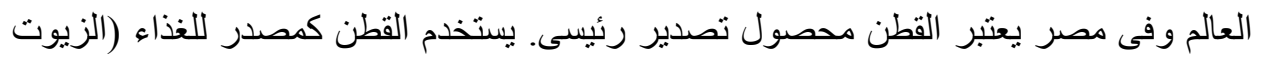

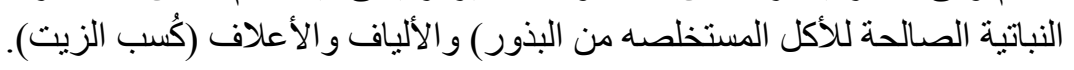

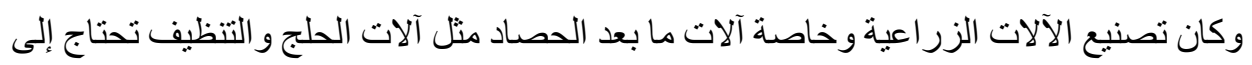
توفير بيانات عن الخصائص الهندسية للمنتج لكي تساعد في تصميم أجزاء الآلاءلة.

ولتحقيق هذا الهدف نم دراسة الخواص الطبيعية والميكانيكية والأيروديناميكية المتعلقة ببذور

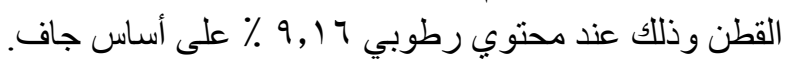

\section{ويمكن تلخيص النتائج كما يلي:}

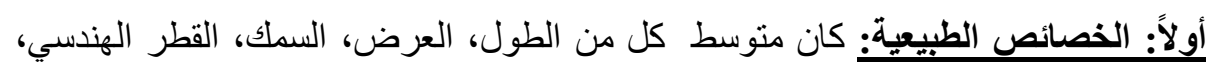

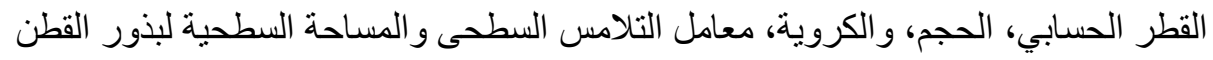

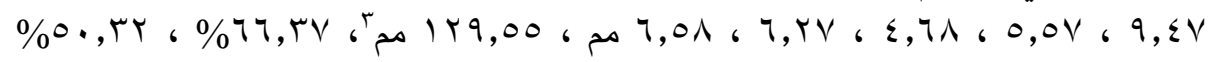

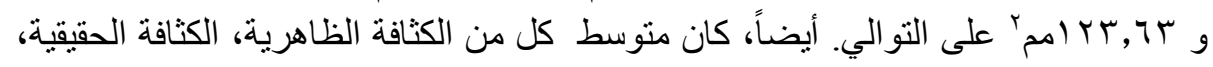

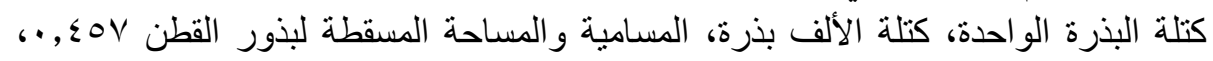

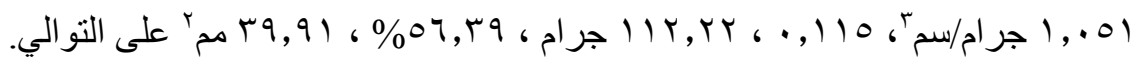

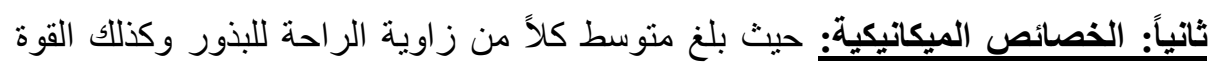

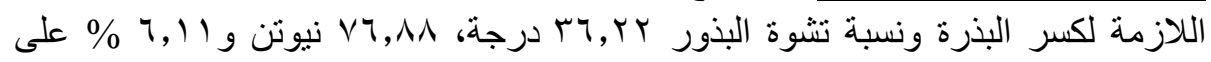

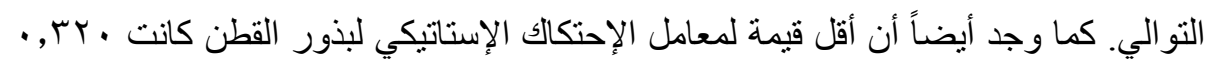

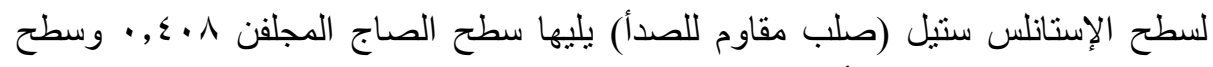

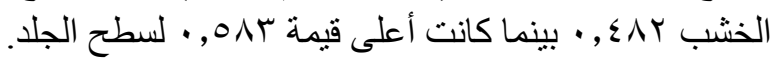

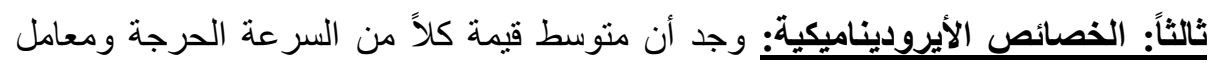

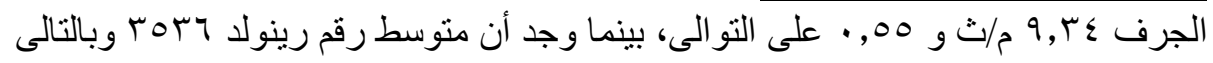
تقع فى نطاق سريان الهواء الإنتقالى.

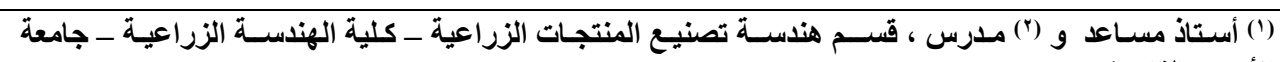
الأزهر بالقاهرة - مصر. 